\title{
mRNA Expression and Role of PPAR $\gamma$ and PPAR $\delta$ in Bovine Preimplantation Embryos Depending on the Quality and Developmental Stage
}

\author{
Katarzyna Suwik ${ }^{1}$, Emilia Sinderewicz ${ }^{1}$, Dorota Boruszewska ${ }^{1}$, Ilona Kowalczyk-Zięba ${ }^{1}$, \\ Joanna Staszkiewicz-Chodor ${ }^{1}$, Krzysztof Lukaszuk ${ }^{2,3,4}$ and Izabela Wocławek-Potocka 1,* \\ 1 Department of Gamete and Embryo Biology, Institute of Animal Reproduction and Food Research, \\ Polish Academy of Sciences, 10-747 Olsztyn, Poland; k.grycmacher@pan.olsztyn.pl (K.S.); \\ e.sinderewicz@pan.olsztyn.pl (E.S.); d.boruszewska@pan.olsztyn.pl (D.B.); \\ i.kowalczyk@pan.olsztyn.pl (I.K.-Z.); j.staszkiewicz-chodor@pan.olsztyn.pl (J.S.-C.) \\ 2 Department of Obstetrics and Gynecological Nursing, Faculty of Health Sciences, Medical University \\ of Gdansk, 80-210 Gdansk, Poland; luka@gumed.edu.pl \\ 3 Department of Obstetrics and Gynecology, The Medical Center of Postgraduate Education, \\ 02-091 Warsaw, Poland \\ 4 INVICTA Fertility and Reproductive Center, 80-850 Gdansk, Poland \\ * Correspondence: i.woclawek-potocka@pan.olsztyn.pl; Tel.: +48-895393155
}

Received: 1 December 2020; Accepted: 5 December 2020; Published: 10 December 2020

check for updates

Simple Summary: The results of the presented study proved that in vitro produced early- and latecleaved bovine embryos express mRNA of peroxisome proliferator-activated receptor $\delta$ (PPAR $\delta$ ) and peroxisome proliferator-activated receptor $\gamma(\operatorname{PPAR} \gamma)$ at all stages of early development $(2-, 4-, 16-$ cell embryo, morula, blastocyst). The expression of PPAR $\delta$ and PPAR $\gamma$ was correlated with the expression of quality markers in bovine blastocysts [sex-determining region Y-box 2 (SOX2), octamer-binding transcription factor 4 (OCT4), placenta-specific 8 (PLAC8), insulin-like growth receptor (IGF1R)]. It was found that in the group of early-cleaved embryos, which is after about $30 \mathrm{~h}$ after fertilization, positive correlations were stronger and more frequent, whereas the negative correlations were typical for group of late-cleaved embryos, which have a first cleave after $36 \mathrm{~h}$.

\begin{abstract}
Peroxisome proliferator-activated receptors (PPARs), a nuclear receptors for prostacyclin $\left(\mathrm{PGI}_{2}\right)$ have been recognized as being essential for early embryo development. The objectives of the present study were to determine if the bovine early- and late-cleaved embryos in different stages of early development express PPAR $\gamma$ and PPAR $\delta$. Since embryo developmental competence depends on numerous biological factors, we evaluated if the expression of PPAR $\gamma$ and PPAR $\delta$ correlate with selected embryo quality markers (SOX2, OCT4, PLAC8, IGF1R) in the in vitro produced embryos at different stages of their development. Developmental rates and embryo quality for early- and late-cleaved embryos were provided according to International Embryo Transfer Society (IETS; developmental stages: 2-, 4-, 16-cell embryo, morula, blastocyst (1-early, 2-developing, 3-expanded, 4-hatched); quality stages: A-high quality, B-moderate quality, C—low quality). We found that bovine embryos expressed mRNA of PPAR $\delta$ and PPAR $\gamma$ at all stages of early development, independently of their quality. In addition, the expression of PPAR $\delta$ and PPAR $\gamma$ correlated with the expression of quality markers in bovine blastocysts. Positive correlations were stronger and more frequent in the group of early-cleaved embryos, whereas the negative correlations were typical for the group of late-cleaved embryos. Obtained results and available literature reports may indicate the participation of $\mathrm{PGI}_{2}$, via PPAR $\delta$ and PPAR $\gamma$, in the processes related to the early embryo development, through the participation of this factor in the modulation of blastocyst hatching, implantation, and post-implantation development.
\end{abstract}


Keywords: embryos; ppar receptors; bovine

\section{Introduction}

Prostacyclin (prostaglandin (PG) $\mathrm{I}_{2}, \mathrm{PGI}_{2}$ ) belongs to the group of prostanoids, which are lipid mediators of the pathological processes, but also essential for the physiology of the female reproduction [1]. $\mathrm{PGI}_{2}$ is essential for pregnancy and early embryo development, including embryo hatching, blastocyst spacing, implantation, and decidualization [2-4]. It was documented that $\mathrm{PGI}_{2}$ is the most abundant PG produced by mouse blastocysts, acting as an antiapoptotic factor during early embryo development [4,5]. Moreover, expression of $\mathrm{PGI}_{2}$ receptors is known to be essential in the embryo development in human, rodents, and ruminants. [6-8]. Prostacyclin is produced by prostaglandin $I_{2}$ synthase (PGIS) [9] and acts through two types of receptors: G-protein-coupled receptor (PTGIR), which induces an increase of intracellular cAMP mediating $\mathrm{PGI}_{2}$ vascular actions and nuclear peroxisome proliferator-activated receptors (PPARs), where the effect of $\mathrm{PGI}_{2}$ action is dependent on the type of the receptor [10-12]. There are three known isoforms of PPARs: PPAR $\alpha$, PPAR $\gamma$, and PPAR $\delta$. PPARs are members of the nuclear receptor superfamily of transcription factors, whose action can be induced by a number of natural compounds such as fatty acids and eicosanoids, hypolipidemic agents and the thiazolidinedione class of antidiabetic drugs [11]. PPARs are activated by heterodimerization with retinoid X receptors (RXR) to form a PPAR/RXR complex. After that, PPAR-RXR heterodimers with the participation of a variety of transcriptional coactivator proteins necessary to activate transcription, bind to a specific DNA sequence called a PPAR-response element (PPREs) of the specific target genes [11,13]. Ligand-dependent activation of PPARs regulates the transcription of the intracrine nuclear pathways engaged in the control of energy, lipid metabolism, cell proliferation, and differentiation $[11,13,14]$.

The presence of PPAR $\delta$ in the trophectoderm is relevant for the $\mathrm{PGI}_{2}$ effect on blastocyst hatching [6]. Deficiency of PPAR $\gamma$ in murine embryos shortly after fertilization led to disturbances in the terminal differentiation of the vascularization in the placenta, and finally to the death of the embryo [7]. It has been shown that in cows, PPAR $\gamma$ mRNA is expressed in all stages of the embryonic development from the oocyte to the blastocyst [8]. Although there is some data in the literature about the prostanoid signaling pathway in the bovine reproductive tract, there is still lack of knowledge about the existence of the receptors for prostacyclin in the bovine preimplantation embryos, resulting in the possibility of $\mathrm{PGI}_{2}$ action during in vitro embryo development.

On the other hand, embryo developmental competence is associated with the expression of the number of biological factors, including maternal mRNAs and proteins, accumulated during oogenesis, which are known as embryo quality markers [15-21]. Among them are transcription factors such as octamer-binding transcription factor 4 (OCT4) and sex-determining region Y-box 2 (SOX2) [7,8], regulating cell differentiation and pluripotency, insulin-like growth factors (IGFs) and its receptors (IGF1R and IGF2R), which improve morphology and growth potential of embryos $[17,18]$ and placenta-specific 8 (PLAC8), which is up-regulated in hatched compared to early blastocysts [19]. Moreover, our last study (in the publication process) showed that the expression of SOX2, OCT4, PLAC8, IGF1R, and IGF2R depends on the developmental stage of the embryo during the preimplantation development. Besides the above-mentioned parameters of the bovine embryo quality and embryonic developmental competences, there is also the timing of the first zygotic cleavage [20,21]. It has been documented that bovine zygotes, cleaved early after oocyte fertilization, are more feasible to develop to the blastocyst stage than their late-cleaving counterparts [22]. Based on the model of the time of the first cleavage, in this study we investigated if the bovine early and late cleaved embryos, being on different stages of early development, express PPAR $\gamma$ and PPAR $\delta$ differently. Moreover, we evaluated if the expression of PPAR $\gamma$ and PPAR $\delta$ correlated with embryo quality markers in the in vitro produced embryos at different stages of development. 


\section{Materials and Methods}

\subsection{Cumulus-oocyte Complexes (COCs) Collection}

All experimental procedures were approved by the Local Animal Care and Use Committee in Olsztyn, Poland (Agreement No. 76/2014/DTN). Ovaries, irrespective of the stage of the estrous cycle, were collected from mature Holstein cows at a local abattoir and transported to the laboratory within $40 \mathrm{~min}$ in sterile $0.9 \%$ saline solution at $37^{\circ} \mathrm{C}$.

Cumulus-oocyte complexes (COCs) were isolated by aspiration from subordinate ovarian follicles, less than $5 \mathrm{~mm}$ in diameter. Using a stereomicroscope, COCs were searched and washed two times in Wash Medium (M199; \#M5017, Sigma Aldrich, Munich, Germany) supplemented with 20 mM HEPES (\#H4034 Sigma Aldrich, Germany), 25 mM sodium bicarbonate (\#S4019 Sigma Aldrich, Munich, Germany), 0.4\% bovine serum albumin (\#A9418 BSA; Sigma Aldrich, Munich, Germany), and $40 \mu \mathrm{g} / \mathrm{mL}$ gentamicin (\#G1272, Sigma, Aldrich, Munich, Germany). Only COCs comprising oocytes with homogeneous ooplasm and surrounded by at least three layers of compact cumulus cells were selected for the study.

\subsection{In Vitro Maturation}

Groups of 50 immature COCs were placed in four-well plates (\#144444, Thermo Fisher Scientific, Waltham, MA, USA) containing $400 \mu \mathrm{L}$ of maturation medium (TCM 199 Maturation Medium (19990/0010, Minitube, Tiefenbach, Germany) supplemented with $0.02 \mathrm{IU} / \mathrm{mL}$ pregnant mare's serum gonadotropin (PMSG, \#G4527, Sigma Aldrich, Munich, Germany), 0.01 IU/mL human chorionic gonadotropin (hCG, \#C0684, Sigma Aldrich, Munich, Germany) and 5\% fetal bovine serum (FBS, \#12106C, Sigma Aldrich, Munich, Germany) and incubated at $38.5^{\circ} \mathrm{C}$ in a $5 \% \mathrm{CO}_{2}$ humidified air atmosphere for $24 \mathrm{~h}$.

\subsection{Semen Capacitation}

For the in vitro fertilization, frozen-thawed semen from the same bull was used throughout the experiment. After thawing (proceeded in water bath, at $38{ }^{\circ} \mathrm{C}$ by $60 \mathrm{~s}$ ), semen was layered below capacitation medium (TL sperm capacitation medium, 19990/0020, Minitube, Tiefenbach, Germany) supplemented with $1 \mathrm{mM}$ sodium pyruvate, $0.6 \% \mathrm{BSA}$ and $0.1 \mathrm{mg} / \mathrm{mL}$ gentamicin) and incubated for $1 \mathrm{~h}$ at $38.5^{\circ} \mathrm{C}$ in $5 \% \mathrm{CO}_{2}$ humidified air atmosphere to allow the recovery of motile sperm through the swim-up procedure. Then, the upper two-thirds of capacitation medium was recovered, centrifuged at $200 \times g$ for $10 \mathrm{~min}$, the supernatant was removed, and the sperm pellet was diluted in an appropriate volume of fertilization medium to give a final concentration of $10^{6}$ sperm $/ \mathrm{mL}$.

\subsection{In Vitro Fertilization}

After in vitro maturation, groups of 50 COCs were placed in fertilization medium (TL fertilization medium; 19990/0030, Minitube, Tiefenbach, Germany) supplemented with $10 \mu \mathrm{g} / \mathrm{mL}$ heparin (\#H3393, Sigma Aldrich, Munich, Germany), 20 mM sodium pyruvate (\#P3662, Sigma Aldrich, Munich, Germany) and $0.5 \%$ BSA and co-incubated with spermatozoa in four-well dishes containing $400 \mu \mathrm{L}$ of fertilization medium for $30 \mathrm{~h}$ at $38.5^{\circ} \mathrm{C}$ in $5 \% \mathrm{CO}_{2}$ humidified air atmosphere. The day of in vitro insemination was considered Day 0. Following fertilization, embryos were separated from cumulus cells by vortexing and washed three times in wash medium. According to Patel et al. [21], for collection of early- and late-cleaved embryos, pools of early-cleaved two-cell embryos $(n=5$; each pool consists of five embryos, for RNA extraction) were collected at $30 \mathrm{~h}$ post-fertilization. Pools of late-cleaved embryos ( $n=5$; each pool consists five embryos, for RNA extraction) were isolated $36 \mathrm{~h}$ post-fertilization. 


\subsection{In Vitro Embryo Culture}

Early- and late-cleaved embryos were cultured separately in four-well dishes, containing $400 \mu \mathrm{L}$ culture medium (SOF; synthetic oviduct fluid medium, SOF; 19990/0040, Minitube, Tiefenbach, Germany) supplemented with amino acids: $10 \mu \mathrm{L} / \mathrm{mL}$ BME (\#B6766, Sigma Aldrich, Munich, Germany) and $20 \mu \mathrm{L} / \mathrm{mL}$ MEM (\#M7145, Sigma Aldrich, Munich, Germany), $3.3 \mathrm{mM}$ sodium pyruvate and $5 \%$ FBS under $400 \mu \mathrm{L}$ of mineral oil at $38.5{ }^{\circ} \mathrm{C}$ in an atmosphere of $5 \% \mathrm{CO}_{2}, 5 \% \mathrm{O}_{2}, 95 \% \mathrm{~N}_{2}$ with high humidity, until they reached blastocysts stage (Day 7).

Developmental rates and embryo quality for early- and late-cleaved embryos were provided by morphological examination on stereo- or inverted microscope at 20,50 or 100× magnification, according to the International Embryo Transfer Society (IETS; International Embryo Transfer Society 1998; developmental stages: 2-, 4-, and 16-cell embryo, morula, blastocyst (1-early, 2-developing, 3-expanded, 4-hatched); quality stages: A-high quality, B-moderate quality, C-low quality).

\subsection{Total RNA Extraction, Reverse Transcription (RT) and Real-Time PCR}

For mRNA expression analysis, total RNA was extracted from five pools of embryos at different stages of their preimplantation development. Total RNA was extracted according to the Arcturus PicoPure RNA Isolation Kit protocol (\#KIT0204, Applied Biosystems, Waltham, MA, USA). The RNA samples were stored at $-80{ }^{\circ} \mathrm{C}$. Before use, RNA content and quality were evaluated by spectrophotometric measurement. The amount of $500 \mathrm{ng}$ of each sample of total RNA was reverse transcribed (according to Super Script III reverse transcriptase protocol (\#18080-044, Invitrogen, Carlsbad, CA, USA). Products of RT were diluted with sterile water $5 \times$ to final concentration $10 \mathrm{ng} / \mu \mathrm{L}$ and stored at $-20^{\circ} \mathrm{C}$ until real-time PCR amplification.

The expression of mRNA for PPAR $\gamma$, PPAR $\delta$, SOX2, OCT4, PLAC8, IGF1R, and IGF2R were measured by real-time PCR. Real-time PCR was performed with an ABI Prism 7900 (Applied Biosystems, Life Technologies, Waltham, MA, USA) sequence detection system using the Maxima Sybr Green/ROX qPCR Master Mix (\#K0222, Thermo Fisher Scientific, Waltham, MA, USA). The polymerase chain reactions (PCR) were performed in 384-well plates. In each reaction, a quantity of cDNA equivalent to 0.15 blastocyst was used. The results of mRNA transcription were normalized to glyceraldehyde-3-phosphate dehydrogenase (GAPDH, an internal control) mRNA levels and were expressed as arbitrary units. The housekeeping gene was chosen using the NormFinder software by comparing the following candidate genes: GAPDH, $\beta$-actin and H2A.1 [23]. The primers were designed using an online software package [24]. The primer sequences and the sizes of the amplified fragments of all of the transcripts are shown in Table 1. For the relative quantification of mRNA levels, Miner software was used [25].

Table 1. Sequences of PCR primers ( $F=$ forward, $R=$ reverse) and GenBank codes for gene transcripts used to assess the relative mRNA abundance of PPAR $\gamma$, PPAR 8, OCT4, SOX2, PLAC8, IGF1R, IGF2R, and GAPDH in bovine embryos at different stages of development. Amplicon sizes are expressed in the number of base pairs (bp).

\begin{tabular}{|c|c|c|c|}
\hline Gene & Gene Bank ID & Primer Sequences $\left(3^{\prime}-5^{\prime}\right)$ & Amplicon Size (bp) \\
\hline PPAR $\gamma$ & NC_037349.1 & $\begin{array}{l}\text { F: AGTGGAGACCGCCCAGGTTTGR: } \\
\text { GGGAGGACTCGGGGTGGTTC }\end{array}$ & 104 \\
\hline PPAR $\delta$ & NM_001083636.1 & $\begin{array}{l}\text { F: TGCGGGGCTTCTCCCATGACR: } \\
\text { AGCCGTGAGTCCTGCCAAGT }\end{array}$ & 81 \\
\hline OCT4 & NM_174580.2 & $\begin{array}{l}\text { F: GAGAAAGACGTGGTCCGAGTGR: } \\
\text { GACCCAGCAGCCTCAAAATC }\end{array}$ & 101 \\
\hline SOX2 & NM_001105463.2 & $\begin{array}{l}\text { F: TGGATCGGCCAGAAGAGGAGR: } \\
\text { CAGGCGAAGAATAATTTGGGGG }\end{array}$ & 89 \\
\hline
\end{tabular}


Table 1. Cont.

\begin{tabular}{cclc}
\hline Gene & Gene Bank ID & \multicolumn{1}{c}{ Primer Sequences $\left(\mathbf{3}^{\prime} \mathbf{- 5}^{\prime} \mathbf{)}\right.$} & Amplicon Size (bp) \\
\hline PLAC8 & NM_001025325.2 & $\begin{array}{l}\text { F: TTTACCGCTCTGTGCCCTTTR: } \\
\text { CCATGTGAACTTGACCAAGCAT }\end{array}$ & 95 \\
\hline IGF1R & NM_001244612.1 & $\begin{array}{l}\text { F: GAGTGGAGAAATCTGCGGGR: } \\
\text { AAATGAGCAGGATGTGGAGGT }\end{array}$ & 110 \\
\hline IGF2R & NM_174352.2 & $\begin{array}{l}\text { F: ACCTCCGATCCTCAATCCCAR: } \\
\text { TGTAGTTGAAGTGCCGGTCC }\end{array}$ & \multirow{2}{*}{82} \\
\hline GAPDH & NM_001034034.2 & $\begin{array}{l}\text { F: CACCCTCAAGATTGTCAGCAR: } \\
\text { GGTCATAAGTCCCTCCACGA }\end{array}$ & 103 \\
\hline
\end{tabular}

PPAR $\gamma$ - peroxisome proliferator-activated receptor $\gamma$; PPAR $\delta$ - peroxisome proliferator-activated receptor $\delta$; OCT4-octamer-binding transcription factor 4; SOX2—sex-determining region Y-box 2; PLAC8 - placenta-specific 8; IGF1R —insulin like growth factor 1 receptor; IGF2R -insulin like growth factor 2 receptor; GAPDH—glyceraldehyde3-phosphate dehydrogenase.

\subsection{Statistical Analysis}

Statistical analyses were conducted using GraphPad PRISM v. 6.0 software (GraphPad Software, Inc., La Jolla, CA, USA). All experimental data are shown as the mean \pm SEM, and the differences were considered significantly different at the $95 \%$ confidence level $(p<0.05)$. The analyses were performed using ANOVA, followed by the Bonferroni's multiple comparison test (Figures 1-3) or correlation analysis followed by Pearson's test (Figures 4 and 5).

\section{Results}

\subsection{The Expression of PPAR $\gamma$ and PPARS in the Bovine Embryo at the Early Stages of Development}

The expression levels of the mRNA of PPAR $\gamma$ (Figure 1A) and PPAR (Figure 1B) were determined in the bovine early- and late-cleaved embryos at the early stages of development: 2-, 4-, 8-, and 16-cells. Similar mRNA expression of PPAR $\gamma$ (Figure 1A, $p>0.05$ ) and PPAR (Figure 1B, $p>0.05$ ) was detected in all stages of early embryo development in early- (Figure $1 \mathrm{~A}, \mathrm{~B}$, white bars) and late-cleaved (Figure 1A,B, black bars) embryos. The expression of PPAR $\gamma$ mRNA was higher in the late-cleaved 4-cell embryos in comparison to the early-cleaved embryos of the same stage of development (Figure 1A, $p<0.05)$. The expression of PPAR $\delta$ mRNA was higher in the late-cleaved 2-cells and 16-cells embryos in comparison to the early-cleaved embryos of the same stages of development (Figure 1B, $p<0.05$ ).

A

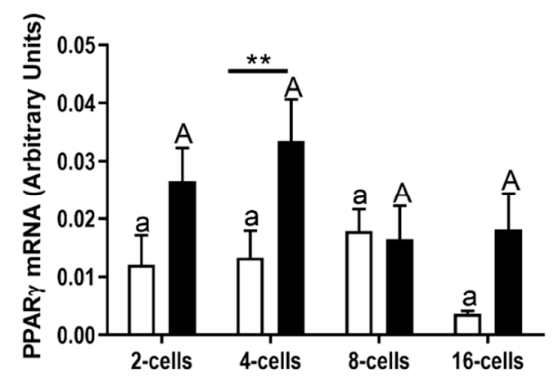

B

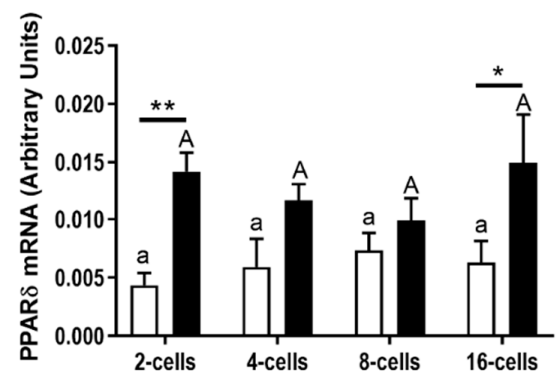

Figure 1. (A) The mRNA relative abundance of the PPAR $\gamma$ and (B) PPAR in bovine embryos at the early stages of development: 2-, 4-, 8-, and 16 cells, produced from early- (white bars) and late-cleaved zygotes (black bars). Small $(\mathrm{a}, \mathrm{b})$ and capital $(\mathrm{A}, \mathrm{B})$ superscript letters indicate differences in the respective mRNA ratios between the various developmental stages of embryos produced from early- and late-cleaved zygotes, respectively. Asterisks denote significant differences in mRNA ratios between the embryos produced from early- and late cleaved zygotes, within this same developmental stage. (* means $p \leq 0.05$; ** mean $p \leq 0.01$ ). Statistical analysis was determined by a two-way analysis of variance (ANOVA) followed by Bonferroni's multiple comparison test $(p<0.05)$. 


\subsection{Expression of PPAR $\gamma$ and PPAR $\delta$ in the Bovine Morulaes}

The expression levels of the mRNA of PPAR $\gamma$ (Figure 2A) and PPAR $\delta$ (Figure 2B) were determined in the early- (Figure 2A,B, white bars) and late-cleaved (Figure 2A,B, black bars) embryos. The expression of PPAR $\gamma$ and PPAR $\delta$ mRNA was higher in morulaes with the lowest quality, produced from the late-cleaved embryos (Figure 2A,B, $p<0.05$ ), in comparison to high and moderate quality morulaes, whereas the expression of PPAR $\gamma$ and PPAR $\delta$ mRNA was similar in morulaes obtained from early-cleaved embryos, independently from their quality (Figure $2 \mathrm{~A}, \mathrm{~B}, p>0.05$ ). The expression of PPAR $\gamma$ and PPAR $\delta$ mRNA in morulaes with the lowest quality was lower in embryos gained from early-cleaved embryos in comparison to embryos gained from late-cleaved embryos (Figure 2A,B, $p<0.05)$.

A

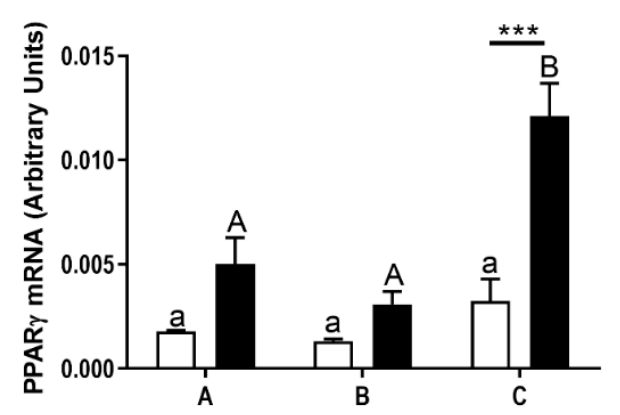

B

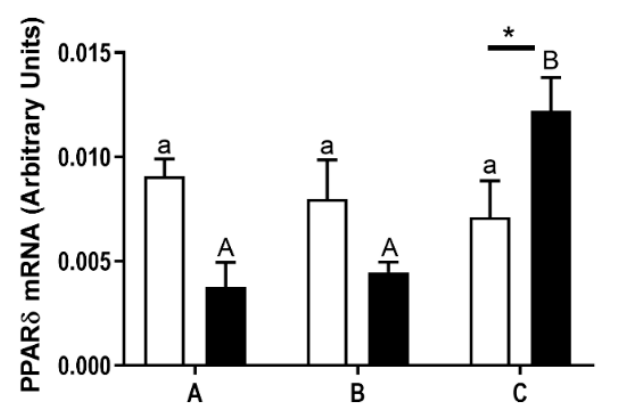

Figure 2. (A) The mRNA relative abundance of the PPAR $\gamma$ and (B) PPAR $\delta$ in varied in quality (A-high, $\mathrm{B}$-moderate, $\mathrm{C}$ - low quality) bovine morulas produced from early- (white bars) and late-cleaved zygotes (black bars). Small (a,b) and capital (A,B) superscript letters indicate differences in the respective mRNA ratios between the various quality groups of morulas, produced from early- and late-cleaved zygotes, respectively. Asterix denotes significant differences in mRNA ratios between the morulas produced from early- and late cleaved zygotes, within the same quality group ( ${ }^{*}$ means $p \leq 0.05$; *** mean $p \leq 0.001)$. Statistical analysis was determined by a two-way ANOVA followed by Bonferroni's multiple comparison test $(p<0.05)$.

\subsection{The Expression of PPAR $\gamma$ and PPAR $\delta$ in the Bovine Blastocysts}

The expression of PPAR $\gamma$ and PPAR $\delta$ mRNA was determined in the early (Figure 3A,D, respectively), developing (Figure 3B,E, respectively), expanded and hatched blastocysts (Figure 3C,F, respectively), produced from early-cleaved (Figure 3, white bars) and late-cleaved embryos (Figure 3, black bars).

The expression of PPAR $\gamma$ mRNA depended on the quality of the blastocysts, gained from earlyand late-cleaved embryos (Figure 3A-C, $p<0.05$ ). The mRNA expression of PPAR $\gamma$ was the highest in the moderate-quality early blastocysts gained from early-cleaved embryos, and in the low-quality early blastocyst gained from late-cleaved embryos (Figure 3A, $p<0.05$ ). In developed blastocyst gained from early-cleaved embryos, the lowest mRNA expression of PPAR $\gamma$ was detected in high quality blastocysts, whereas the greatest mRNA expression of PPAR $\gamma$ was detected in low-quality embryos (Figure 3B, $p<0.05)$. The mRNA expression of PPAR $\gamma$ in high- and low- quality developed blastocyst gained from late-cleaved embryos was similar. The expression of PPAR $\gamma$ in moderate-quality blastocysts was not detected (Figure 3B, $p>0.05$ ). In expanded blastocysts gained from early-cleaved embryos, the mRNA expression of PPAR $\gamma$ was higher in moderate-quality blastocysts in comparison to high- and lowquality blastocysts (Figure 3C, $p<0.05$ ). Expanded blastocysts obtained from late-cleaved embryos presented a similar PPAR $\gamma$ mRNA level in all examined classes of quality. 
The mRNA expression of PPAR $\gamma$ differed also among early- and late-cleaved embryos at the blastocyst stage of development. The greater mRNA levels of PPAR $\gamma$ was documented in low-quality early (Figure 3A, $p<0.05$ ) and expanded blastocysts (Figure 3B, $p<0.05$ ), and in high-quality developed (Figure 3B, $p<0.05$ ) and expanded blastocysts (Figure 3C, $p<0.05$ ), gained from late-cleaved embryos in comparison to early-cleaved embryos at the equivalent stages of development. Moreover, the mRNA expression of PPAR $\gamma$ was higher in low-quality developed (Figure $3 \mathrm{~B}, p<0.05$ ) and high-quality hatched blastocysts (Figure $3 C, p<0.05$ ) gained from early-cleaved embryos in comparison to blastocysts in the same developmental stages, produced from late-cleaved embryos.

A
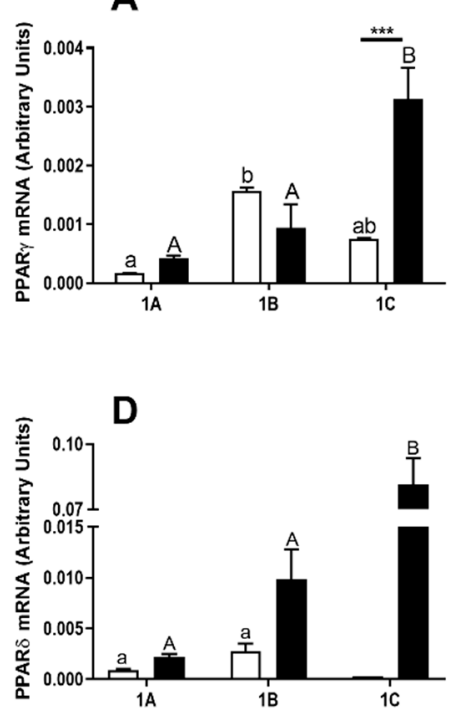

B
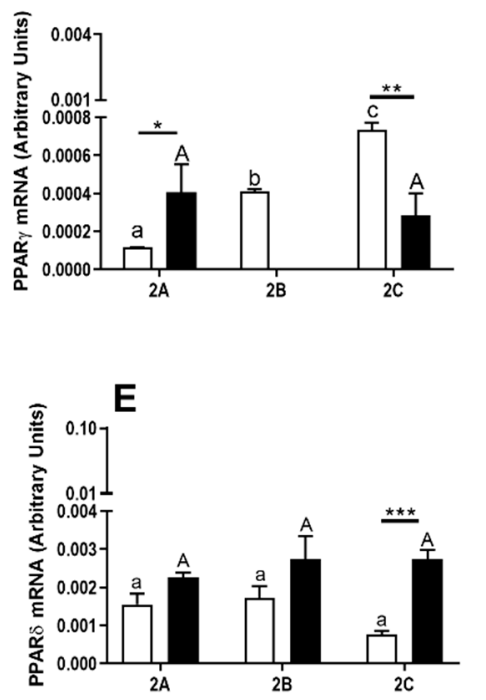

C
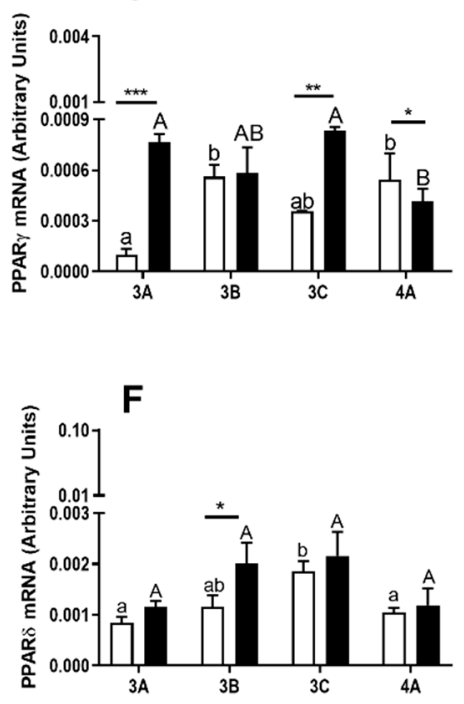

Figure 3. (A-C) The mRNA relative abundance of the PPAR $\gamma$ and (D-F) PPAR $\delta$ in varied in quality (A-high, B-moderate, C-low quality) and developmental stage bovine blastocysts (1-early blastocyst (Figure 3A,D), 2-developed blastocyst (Figure 3B,E), 3-expanded and 4-hatched blastocyst (Figure 3C,F) produced from early- (white bars) and late-cleaved zygotes (black bars). Small (a,b) and capital $(\mathrm{A}, \mathrm{B})$ superscript letters indicate differences in the respective mRNA ratios between the various quality groups of blastocysts, produced from early- and late-cleaved zygotes, respectively. Asterix denotes significant differences mRNA ratios between the blastocysts produced from earlyand late cleaved zygotes, within this same developmental stage and quality group ( ${ }^{*}$ means $p \leq 0.05$; ** mean $p \leq 0.01 ;{ }^{* *}$ mean $\left.p \leq 0.001\right)$. Statistical analysis was determined by a two-way ANOVA followed by Bonferroni's multiple comparison test $(p<0.05)$.

The mRNA expression of PPAR $\delta$ was blastocyst quality-dependent in early blastocysts gained from late-cleaved embryos and in expanded blastocysts obtained from early-cleaved embryos (Figure 3D,F, $p<0.05)$. The greatest mRNA level of PPAR $\delta$ was detected for low-quality blastocysts, whereas the lowest mRNA level was detected in high-quality blastocysts (Figure 3D,F, $p<0.05$ ). The mRNA expression of PPAR $\delta$ was higher in low-quality developing and moderate-quality expanded blastocysts produced from late-cleaved embryos in comparison to early-cleaved embryos at the same stages of development (Figure 3E,F, $p<0.05$ ).

3.4. Correlation between mRNA Expression of PPAR $\gamma$, PPAR $\delta$ and Embryo Quality Markers (IGF1R, IGF2R, PLAC8, OCT4, SOX2) in the Bovine Blastocysts

The correlations between PPAR $\gamma$ (Figure 4), PPAR $\delta$ (Figure 5) and embryo quality markers (IGF1R, IGF2R, PLAC8, OCT4, SOX2) have been studied for various quality and developmental stages blastocysts, produced from early- (Figures 4A and 5A) and late-cleaved embryos (Figures 4B and 5B). Exact values (Table S1) and $p$-values (Table S2) of mRNA expression of PPAR $\gamma$ and PPAR $\delta$, and embryos at different stages of development and quality are documented in Supplementary files. 
In the group of blastocysts produced from early-cleaved embryos, numerous positive and three negative correlations between PPAR $\gamma$ and embryo quality markers were found (Figure 4A). The most numerous and strongest relationships were observed for developing blastocysts, regardless of quality. The low-quality early and expanded blastocysts revealed weaker and fewer correlations between $\operatorname{PPAR} \gamma$ and embryo quality markers mRNA expression in comparison to moderate- and high-quality blastocysts (Figure 4A). The relationships between PPAR $\gamma$ and IGF1R, IGF2R, PLAC8, OCT4 and SOX2 mRNA expression were also found in the group of blastocysts produced from late-cleaved embryos, irrespective of embryo quality and stage of development (Figure 4B). However, the general number of correlations was lower and number of negative correlations was higher in the group of blastocysts produced from late-cleaved embryos in comparison with the group of blastocysts received from early-cleaved embryos.

EARLY CLEAVED EMBRYOS

\begin{tabular}{|c|c|c|c|c|c|c|}
\hline \multirow{2}{*}{\multicolumn{2}{|c|}{$r$ - value }} & \multicolumn{5}{|c|}{ embryo quality markers mRNA expression } \\
\hline & & \multirow{2}{*}{$\begin{array}{l}\text { IGF1R } \\
0.9996\end{array}$} & \multirow{2}{*}{$\frac{\text { IGF2R }}{0.9997}$} & \multirow{2}{*}{$\begin{array}{l}\text { PLAC8 } \\
0.5587\end{array}$} & \multirow{2}{*}{$\begin{array}{c}\text { OCT4 } \\
-0.1325\end{array}$} & \multirow{2}{*}{$\begin{array}{c}\text { SOX2 } \\
-0.7583\end{array}$} \\
\hline \multirow{20}{*}{ 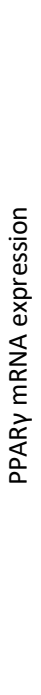 } & \multirow{2}{*}{$1 \mathrm{~A}$} & & & & & \\
\hline & & 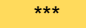 & 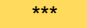 & * & & ** \\
\hline & \multirow{2}{*}{ 1B } & -0.9583 & 0.1923 & 0.5981 & 0.9932 & 0.3189 \\
\hline & & *** & & * & *** & \\
\hline & \multirow{2}{*}{ 1C } & -0.6072 & -0.3744 & 0.1099 & 0.1117 & -0.4948 \\
\hline & & ** & & ns & ns & \\
\hline & \multirow{2}{*}{$2 A$} & 0.9901 & 0.8643 & 0.9901 & 0.8334 & 0.8495 \\
\hline & & *** & *** & *** & *** & *** \\
\hline & \multirow{2}{*}{ 2B } & 0.8729 & 0.8625 & 0.6253 & 0.9477 & 0.9404 \\
\hline & & *** & *** & ** & *** & *** \\
\hline & \multirow{2}{*}{$2 C$} & 0.9232 & 0.9265 & -0.2422 & 0.8492 & 0.6528 \\
\hline & & *** & *** & & *** & ** \\
\hline & \multirow{2}{*}{$3 A$} & 0.9607 & 0.9636 & 0.6681 & & 0.9647 \\
\hline & & $\star \star \star *$ & $* * *$ & ** & & *** \\
\hline & \multirow{2}{*}{ 3B } & 0.9649 & 0.9656 & 0.7115 & -0.4739 & 0.4737 \\
\hline & & *** & *** & ** & & \\
\hline & \multirow{2}{*}{$3 C$} & 0.5204 & 0.4837 & 0.8848 & 0.5451 & 0.8102 \\
\hline & & * & * & *** & * & $\star \star \star *$ \\
\hline & \multirow{2}{*}{ 4A } & 0.6107 & 0.6404 & -0.146 & 0.6413 & 0.1075 \\
\hline & & ** & ** & & ** & \\
\hline
\end{tabular}

LATE CLEAVED EMBRYOS

\begin{tabular}{|c|c|c|c|c|c|c|}
\hline \multirow{2}{*}{\multicolumn{2}{|c|}{$r$ - value }} & \multicolumn{5}{|c|}{ embryo quality markers mRNA expression } \\
\hline & & \multirow{2}{*}{$\begin{array}{c}\text { IGF1R } \\
-0.8273\end{array}$} & \multirow{2}{*}{$\begin{array}{c}\text { IGF2R } \\
-0.8784\end{array}$} & \multirow{3}{*}{$\begin{array}{r}\text { PLAC8 } \\
-0.1025\end{array}$} & \multirow{2}{*}{$\begin{array}{r}\text { ОCT4 } \\
-0.8381\end{array}$} & \multirow{3}{*}{$\begin{array}{c}\text { SOX2 } \\
-0.05722\end{array}$} \\
\hline \multirow{17}{*}{ 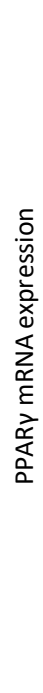 } & \multirow{2}{*}{$1 \mathrm{~A}$} & & & & & \\
\hline & & $* * *$ & $* * *$ & & $* * *$ & \\
\hline & \multirow{2}{*}{ 1B } & 0.8706 & & 0.4734 & 0.4293 & 0.8347 \\
\hline & & $* * *$ & & * & * & *** \\
\hline & 1C & 0.4404 & 0.6369 & -0.2399 & -0.1038 & 0.0428 \\
\hline & $2 A$ & 0.3985 & 0.409 & 0.3453 & 0.1706 & -0.2301 \\
\hline & \multicolumn{6}{|l|}{ 2B } \\
\hline & \multirow{2}{*}{ 2C } & -0.4836 & -0.4998 & 0.1545 & -0.9996 & -0.02657 \\
\hline & & * & * & & *** & \\
\hline & \multirow{2}{*}{ 3A } & -0.8146 & -0.7822 & -0.5937 & -0.8129 & -0.2387 \\
\hline & & $\star * *$ & ** & * & $* * *$ & \\
\hline & \multirow{2}{*}{ 3B } & 0.7167 & 0.7043 & 0.3842 & -0.3742 & -0.8104 \\
\hline & & ** & ** & & & *** \\
\hline & \multirow{2}{*}{$3 C$} & 0.8936 & & -0.8706 & -0.8042 & 0.8973 \\
\hline & & $\star * * *$ & & $* * *$ & $* * *$ & $* * *$ \\
\hline & \multirow{2}{*}{$4 A$} & 0.5991 & -0.8706 & -0.9452 & -0.9345 & -0.6453 \\
\hline & & * & *** & *** & $* * *$ & $* *$ \\
\hline
\end{tabular}

Figure 4. The correlation between PPAR $\gamma$ and embryo quality markers (IGF1R, IGF2R, PLAC8, OCT4, SOX2) mRNA expression in the bovine blastocyst-stage embryos developed from early-cleaved embryos (yellow table) and late-cleaved embryos (grey table). The numbers 1, 2, 3, 4 indicate developmental stage of blastocysts (early, developed, expanded, and hatched, respectively). The superscript letters A, $\mathrm{B}, \mathrm{C}$ indicate quality of the blastocyst (high, moderate, and low, respectively). The white field indicates a non-significant $\mathrm{r}$-value $(\mathrm{r}<0.4)$. The ${ }^{*},{ }^{* *}$, and ${ }^{* * *}$ and color tonality indicate strength of the correlation (weak $(0.41<\mathrm{r}<0.6$, light tonality), moderate $(0.61<\mathrm{r}<0.8$, moderate tonality) and strong correlation $(0.81<\mathrm{r}<1.0$, dark tonality), respectively). $\mathrm{r}$-values of negative and statistically significant correlations were marked in red. The correlation analysis was followed by a Pearson test.

The great number of correlations between mRNA expression of PPAR $\delta$ and embryo quality markers in bovine blastocysts were observed (Figure 5A,B). In the group of blastocysts gained from early-cleaved embryos, the observed correlations were exclusively positive (Figure 5A), whereas in blastocysts obtained from the late-cleaved embryos many negative relationships were noticed (Figure 5B). The greatest number of correlations occurred between PPAR $\delta$-SOX2 and PPAR $\delta$-IGF2R in the group of early-cleaved blastocysts, independently of blastocyst quality and developmental stage (Figure 5A). 
EARLY CLEAVED EMBRYOS

\begin{tabular}{|c|c|c|c|c|c|c|}
\hline \multirow{2}{*}{\multicolumn{2}{|c|}{$r$ - value }} & \multicolumn{5}{|c|}{ embryo quality markers mRNA expression } \\
\hline & & \multirow{2}{*}{$\begin{array}{c}\text { IGF1R } \\
0.4181\end{array}$} & \multirow{2}{*}{$\begin{array}{l}\text { IGF2R } \\
0.4153\end{array}$} & \multirow{2}{*}{$\begin{array}{c}\text { PLAC8 } \\
-0.874\end{array}$} & \multirow{2}{*}{$\begin{array}{c}\text { OCT4 } \\
-0.3885\end{array}$} & \multirow{3}{*}{$\begin{array}{c}\text { SOX2 } \\
-0.3136\end{array}$} \\
\hline \multirow{19}{*}{ 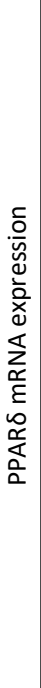 } & 10 & & & & & \\
\hline & $\mathbf{I A}$ & * & * & & & \\
\hline & & 0.4089 & 0.7744 & 0.197 & -0.5649 & 0.09893 \\
\hline & 1B & * & ** & & & \\
\hline & 1C & 0.02561 & 0.02751 & 0.1534 & -0.1348 & 0.1294 \\
\hline & \multirow{2}{*}{$2 \mathrm{~A}$} & 0.9328 & 0.9265 & -0.1855 & 0.07407 & 0.9051 \\
\hline & & & & & & \\
\hline & \multirow{2}{*}{ 2B } & 0.9806 & 0.9999 & 0.5815 & 0.9005 & 0.7767 \\
\hline & & 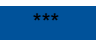 & & * & 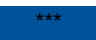 & ** \\
\hline & \multirow{2}{*}{ 2C } & 0.7471 & 0.7632 & \multirow[t]{2}{*}{-0.5729} & 0.8444 & 0.9849 \\
\hline & & ** & ** & & ** & $\pi \star \star *$ \\
\hline & \multirow{2}{*}{$3 A$} & \multirow[t]{2}{*}{0.1736} & 0.9306 & \multirow[t]{2}{*}{0.3189} & 0.9946 & 0.7786 \\
\hline & & & & & & ** \\
\hline & \multirow{2}{*}{ 3B } & \multirow[t]{2}{*}{-0.4053} & \multirow[t]{2}{*}{-0.3801} & \multirow[t]{2}{*}{0.1929} & 0.7091 & 0.9574 \\
\hline & & & & & ** & \\
\hline & \multirow{2}{*}{$3 C$} & \multirow[t]{2}{*}{0.1289} & \multirow[t]{2}{*}{0.1289} & 0.9745 & 0.9459 & 0.9869 \\
\hline & & & & & $\pi \approx *$ & *** \\
\hline & \multirow{2}{*}{$4 A$} & 0.9448 & 0.9131 & 0.6562 & \multirow[t]{2}{*}{0.09555} & 0.616 \\
\hline & & & & $* *$ & & $* *$ \\
\hline
\end{tabular}

LATE CLEAVED EMBRYOS

\begin{tabular}{|c|c|c|c|c|c|c|}
\hline \multirow{2}{*}{\multicolumn{2}{|c|}{$r$ - value }} & \multicolumn{5}{|c|}{ embryo quality markers mRNA expression } \\
\hline & & \multirow{2}{*}{$\begin{array}{l}\text { IGF1R } \\
0.6406\end{array}$} & \multirow{2}{*}{$\begin{array}{c}\text { IGF2R } \\
0.7068\end{array}$} & \multirow{2}{*}{$\begin{array}{r}\text { PLAC8 } \\
-0.3625\end{array}$} & \multirow{2}{*}{$\begin{array}{c}\text { OCT4 } \\
0.7937\end{array}$} & \multirow{2}{*}{$\begin{array}{c}\text { SOX2 } \\
-0.2049\end{array}$} \\
\hline \multirow{19}{*}{ 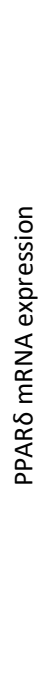 } & \multirow{2}{*}{$1 \mathrm{~A}$} & & & & & \\
\hline & & $\star * *$ & $* *$ & & $* *$ & \\
\hline & \multirow{2}{*}{ 1B } & 0.8677 & \multirow[t]{2}{*}{0.6818} & 0.9212 & \multirow[t]{2}{*}{0.5136} & \multirow[t]{2}{*}{0.5217} \\
\hline & & $* * *$ & & $* * *$ & & \\
\hline & \multirow{2}{*}{ 1C } & 0.7311 & \multirow[t]{2}{*}{0.5592} & \multirow[t]{2}{*}{0.3849} & 0.6232 & 0.5919 \\
\hline & & $* *$ & & & $* *$ & * \\
\hline & \multirow{2}{*}{$2 A$} & 0.8355 & 0.8246 & \multirow[t]{2}{*}{0.4113} & 0.4441 & \multirow[t]{2}{*}{0.4472} \\
\hline & & $\star * *$ & $* * *$ & & * & \\
\hline & \multirow{2}{*}{ 2B } & 0.7767 & 0.7294 & 0.7536 & \multirow[t]{2}{*}{-0.3924} & \multirow[t]{2}{*}{0.1667} \\
\hline & & ** & ** & ** & & \\
\hline & \multirow{2}{*}{ 2C } & -0.7004 & -0.6955 & 0.8581 & -0.9892 & \multirow[t]{2}{*}{-0.4777} \\
\hline & & $\star *$ & $* *$ & $* * *$ & $* * *$ & \\
\hline & $3 A$ & -0.3335 & -0.5659 & -0.4801 & 0.5581 & 0.268 \\
\hline & \multirow{2}{*}{ 3B } & \multirow[t]{2}{*}{-0.3878} & \multirow[t]{2}{*}{-0.362} & \multirow[t]{2}{*}{-0.3968} & \multirow{2}{*}{$\begin{array}{c}-0.5632 \\
*\end{array}$} & 0.7891 \\
\hline & & & & & & ** \\
\hline & \multirow{2}{*}{ 3C } & \multirow[t]{2}{*}{0.4731} & -0.9659 & \multirow[t]{2}{*}{0.3695} & -0.9994 & 0.4009 \\
\hline & & & $* * *$ & & $* * *$ & \\
\hline & An & -0.5394 & -0.8736 & -0.1843 & -0.3712 & -0.9413 \\
\hline & 4A & * & $* * *$ & & & 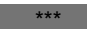 \\
\hline
\end{tabular}

Figure 5. The correlation between PPAR $\delta$ and embryo quality markers (IGF1R, IGF2R, PLAC8, OCT4, SOX2) mRNA expression in the bovine blastocyst-stage embryos developed from early-cleaved embryos (blue table) and late-cleaved embryos (grey table). The numbers 1, 2, 3, 4 indicate developmental stage of blastocyst (early, developed, expanded, and hatched, respectively). The superscript letters A, B, C indicate quality of the blastocyst (high, moderate, and low, respectively). The white field indicates a non-significant $\mathrm{r}$-value $(\mathrm{r}<0.4)$. The ${ }^{*}{ }^{* *}$, and ${ }^{* * *}$ indicate strength of correlation (weak $(0.41<\mathrm{r}<0.6)$, moderate $(0.61<\mathrm{r}<0.8)$ and strong correlation $(0.81<\mathrm{r}<1.0)$, respectively). $\mathrm{r}$-values of negative, statistically significant correlations were marked in red. The correlation analysis was followed by a Pearson test.

\section{Discussion}

The PPAR $\alpha$ and PPAR $\gamma$ were considered to be expressed during late embryonic development [26], until the study of Mohan et al. [8], which described PPAR $\gamma$ mRNA expression during early bovine embryo development from the oocyte to the blastocyst. However, this study is the first to show an expression of both PPAR $\gamma$ and PPAR $\delta$ in the bovine preimplantation embryo, correlating with embryo quality markers at different stages of development. We have found the presence of PPAR $\gamma$ and PPAR $\delta$ in 2-, 4-, 8-, and 16-cell bovine embryos, morulaes and early, developed, expanded, and hatched blastocysts, produced from high- and low-quality oocytes. Moreover, the expression of PPARs was dependent of the developmental stage of the embryos and their quality. The mRNA expression of PPAR $\gamma$ was greater in 4-cells embryos, whereas mRNA expression of PPAR $\delta$ was greater in 2- and 16-cells embryos in comparison to the other embryos in early developmental stages, suggesting possible $\mathrm{PGI}_{2}$ influence on the bovine early embryo development. These findings are consistent with the study of Huang et al. [3], who demonstrated that the supplementation of the culture medium with the $\mathrm{PGI}_{2}$ agonist resulted in the enhanced blastocyst hatching. However, this effect was not achieved through the membrane G-protein-coupled receptors, which accounts for the role of PPARs in the extended blastocyst hatching rate. The elevated mRNA levels of the examined PPARs during 2- and 4-cell stages suggest possible $\mathrm{PGI}_{2}$ influence before the maternal genome transition during early embryo development. On the other hand, the increased mRNA abundance of PPAR $\delta$ at 16-cell stage, when the embryo genome is activated, suggests that the probable inclusion of the $\mathrm{PGI}_{2} / \mathrm{PPAR} \delta$ pathway during embryo development is also under the embryo genome control.

In this study, we also detected the expression of PPAR $\gamma$ and PPAR $\delta$ in morulas and blastocysts, dependently on their quality, determined according to IETS guidelines. We found that the expression of the examined PPARs was higher in low-quality morulas, produced from late-cleaved zygotes, 
which underwent the first embryonic division after $36 \mathrm{~h}-$ not after $30 \mathrm{~h}$, as their early-cleaved counterparts. Similarly, only low quality early and developed blastocyst revealed differences between PPARs expression in groups produced from early- and late-cleaved zygotes. This might suggest the existence of some counterbalancing mechanisms, engaging $\mathrm{PGI}_{2}$ to support low quality embryos to grow and develop. On the other hand, PPAR $\gamma$ mRNA expression in hatched blastocysts was higher in embryos produced from early-cleaved zygotes. Taking into consideration that early cleaved bovine embryos have greater developmental competences [20,21], our results seem to be consistent with a study carried out on mice, demonstrating the role of PPAR $\gamma$ in the terminal embryo differentiation and placental vascularization, preventing embryonic lethality [7]. What is more, PPAR $\gamma$ was involved in the accumulation of lipids in trophoblast, its differentiation and invasion during early pregnancy as well as regulation of conceptuses elongation [26-28].

PPAR $\delta$ is known as the omnipresent expressed receptor, playing an extensive role during early embryo development [29]. Accordingly, the mRNA expression profile of PPAR $\delta$ documented in this study, is surprising. We have found the expression of PPAR $\delta$ in all examined groups of embryos, but the higher expression of PPAR $\delta$ was detected in the lowest quality morulaes and developing blastocysts, which were produced from late-cleaved embryos. On the other hand, the PPAR $\delta$, which was expressed higher in the bovine blastocysts in comparison to PPAR $\gamma$, is known as the part of the $\mathrm{PGI}_{2} / \mathrm{PPAR}$ axis, participating in blastocyst hatching in vitro. The lack of the active $\mathrm{PGI}_{2}-\mathrm{PPAR} \delta$ system caused failures in blastocyst formation and hatching but did not impair blastocyst development $[5,6,30]$. Moreover, in rodents, PPAR $\delta$ activation by $\mathrm{PGI}_{2}$ increased also the quality of blastocyst implantation sites, blastocyst spacing, and decidualization [2,31,32]. Although little was known about the PPAR $\delta$ involvement in the embryonic development in farm animals, Guo et al. [31] has recently demonstrated that the activation of PPAR $\delta$ facilitated blastocyst hatching via fatty acid oxidation in pigs. Besides, treatment of porcine parthenotes with the PPAR $\delta$-specific agonist improved blastocyst quality via increasing the total cell number, which suggests that PPAR $\delta$ affected the developmental competences of the embryo [31]. The presence of PPAR $\delta$ and its role during the peri-implantation period was also documented in the ovine trophoblast [32]. In addition, Roberti et al. [33] suggested that PPAR $\delta$ was the key factor in post-implantation development, preventing embryo resorption. Taking the above into consideration, the presence of PPARs seems to be essential during bovine embryo development, but mechanisms of their regulatory function need to be proven in further studies. Special attention should be directed to the ability of PPARs to heterodimerization with RXRs, which mainly determines the possibility of DNA binding and activation of gene transcription [13]. It has been shown that mice lacking of RXR $\delta$, which is major RXR isoform in placenta, were shown similar lethal placental defects

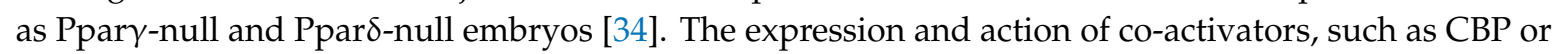
p300 factors, for which have been shown that deficiency caused embryo dying during early gestation mice, should also be taken into account [13].

Despite numerous documents, showing the presence of PPARs in embryonic development and its influence on the key events as blastocyst hatching, implantation and decidualization, the mechanisms of PPARs/PGI 2 action are still unknown. The embryo developmental competences are reflected by the expression of biological factors, as well as the time of the embryo first cleavage. In this study, we also conducted analyses of potential correlations of the mRNA expression of PPARs and the mRNA expression of SOX2, IGF1R, IGF2R, OCT4, and PLAC8. We planned to establish whether the involvement of PPARs during bovine embryo development was related to the abundance of expression of the embryo developmental quality markers.

We have found many correlations between mRNA expression of examined PPARs and mRNA expression of SOX2, IGF1R, IGF2R, OCT4, PLAC8. Interestingly, negative correlations between mRNA expression of PPAR $\gamma$ and PPAR $\delta$ and mRNA expression of chosen quality markers were typical only for blastocysts produced from late-cleaved embryos. The above data suggest, that the presence of PPARs in the late-cleaved blastocysts or/and in low-quality embryos, being at the earlier stages of development, is not an effect of the regulatory mechanism, leading to improvement of 
their developmental competences, but rather some constitutive characteristics during bovine embryo development. Moreover, negative correlations between the expression of PPARs and factors involved in the proliferation and differentiation indicate that PPARs are engaged in some kinds of mechanisms regulating pregnancy establishment depending on the quality and developmental competences of the embryo. The positive correlations were documented in both early- and late-cleaved groups of blastocysts. However, the general number of correlations was lower and weaker in the group of blastocysts produced from the late-cleaved embryos in comparison to early-cleaved ones. In addition, the most numerous and strongest relationships were observed between PPAR $\gamma$ and IGF1R, IGF2R, OCT4, and SOX2 in developing blastocysts, regardless of their quality.

The greatest number of correlations occurred between PPAR $\delta-S O X 2$ and PPAR $\delta-I G F 2 R$ in the group of early-cleaved blastocysts, independently on the blastocyst quality and developmental stages. The SOX2, together with OCT4, both belong to the transcription factors, affecting embryo development via controlling cell proliferation, pluripotency, and differentiation [15,35]. Embryos with reduced expression of SOX2 did not develop into blastocysts [16]. What is more, the lack of SOX2 in bovine zygotes decreased the blastocyst rates due to deficiency of maternal-embryonic genome transition [36]. Besides, in early bovine embryos, transcripts of SOX2 were also described in oocytes [37]. Positive correlations of PPARs and SOX 2 mRNA expression, documented mostly in blastocysts produced from high quality oocytes, might be caused by the presence of the SOX2 during all the steps of embryo development. This particular strong and abundant correlation was observed between SOX2 and PPAR $\delta$ expression, which is known as the factor playing a significant role in blastocyst hatching and embryo development in general [29]. Its relationship with SOX2 expression may indicate the importance of PPAR $\delta$ during bovine embryo development. In mice, the lack of the OCT4 resulted in arresting the embryos at multi-cell stages, leading to the decreased blastocyst rate [38]. The expression of OCT4 was also greater in early-cleaved embryos in comparison to the late-cleaved embryos $[39,40]$, which is a consequence of the reduced developmental competences of the low-quality oocytes. Similarly, in this study, we observed positive correlations between examined PPARs and OCT4 expression in blastocysts produced from early-cleaved zygotes, whereas in the group of blastocysts produced from late-cleaved zygotes were found multiple negative correlations. The dependence of OCT4 expression on the bovine embryo developmental stage and quality was also found earlier (own unpublished data). The described correlations of SOX2, OCT4, and PPARs, account for the possible, multifunctional role of PPARs during bovine early embryo development.

It has been shown before that IGF and its receptors, IGF1R and IGF2R are also interdependent with the growth potential of the embryos $[17,18,41]$. In cows, the expression of IGF1R and IGF2R was the greatest during embryonic genome activation and in the hatched blastocyst [42], indicating its early role after fertilization as well as during implantation and formation of filamentous conceptus. IGF1R and IGF2R were also differentially expressed during the subsequent developmental stages of bovine embryos (own unpublished data). In our study, we found strong, positive correlations between the expression of IGF2R and examined PPARs in the early-cleaved embryos in comparison to the group of late-cleaved zygotes, which indicates the role of PPAR $\gamma$ and PPAR $\delta$ during the peri-implantation period of the bovine embryo development.

It was demonstrated that PLAC8 was also involved in the early embryo development. The presence of PLAC8 was found for different developmental stages of the bovine embryo (own unpublished data). Furthermore, the expression of the PLAC 8 was up-regulated in expanded and hatched compared to early blastocysts [21]. The higher expression of PLAC 8 was documented in the blastocysts, which resulted in calf delivery compared to the blastocysts which had been resorbed $[43,44]$. Although the role of PLAC8 during early bovine embryo development is already established, in this study we documented the lowest number of correlations between the expression of PLAC 8 and PPARs in blastocysts, which suggests that these pathways, both involved in blastocyst development, might act independently. 


\section{Conclusions}

In summary, mRNA of PPAR $\delta$ and PPAR $\gamma$ were expressed in the bovine embryos at different stages of development, independently of their quality. The expression of PPAR $\delta$ and PPAR $\gamma$ correlated with the expression of quality markers in bovine blastocysts. Positive correlations were stronger and more abundant in the group of early-cleaved embryos, whereas the negative correlations were typical for the group of late-cleaved embryos. According to the above results and literature reports, we suggest the role of $\mathrm{PGI}_{2}$, acting via PPAR $\delta$ and $\mathrm{PPAR} \gamma$, in mechanisms regulating bovine early embryo development, presumably via the modulation of blastocyst hatching, implantation, and post-implantation development. For the thorough examination of the mentioned mechanisms, further studies are required.

The obtained data provided additional information on the preimplantation development of the bovine embryo. Differences in the expression of genes for prostacyclin receptors and genes that are markers of early embryonic development, as well as the presented correlations, can increase information on the production of in vitro embryo development, which is a frequently used method in assisted reproductive technology (ART). In addition, the obtained data on gene expression regarding the various developmental stages as well as the quality of the embryos influence, can be used in ART of dairy and beef cattle, where morphological assessment is one of the main tools for embryo assessment.

Supplementary Materials: The following are available online at http://www.mdpi.com/2076-2615/10/12/2358/s1, Table S1: Exact values of mRNA expression of PPAR $\gamma$ and PPAR $\delta$ and embryos at different stages of development and quality, Table S2: $p$-values of mRNA expression of PPAR $\gamma$ and PPAR $\delta$ and embryos at different stages of development and quality.

Author Contributions: Conceptualization, I.W.-P.; methodology, I.W.-P.; software, K.S., E.S.; validation, K.S., E.S.; formal analysis, K.S.; investigation, K.S., E.S., D.B., I.K.-Z.; J.S.-C., resources, D.B., I.K.-Z.; J.S.-C.; data curation, I.K.-Z.; writing — original draft preparation, K.S., E.S.; writing—review and editing, K.S.; visualization, K.S., E.S.; supervision, I.W.-P., K.Ł.; project administration, I.W.-P.; funding acquisition, I.W.-P. All authors have read and agreed to the published version of the manuscript.

Funding: This research was supported by Grants-in-Aid for Scientific Research from the Polish National Science Centre: NCN 2015/17/B/NZ9/011688.

Acknowledgments: The authors are indebted to the owner of the slaughterhouse (Zaklady Miesne "Warmia", Biskupiec, Poland) for facilitating the material collection.

Conflicts of Interest: The authors declare no conflict of interest.

\section{References}

1. Loftin, C.D.; Tiano, H.F.; Langenbach, R. Phenotypes of the COX-deficient mice indicate physiological and pathophysiological roles for COX-1 and COX-2. Prostaglandins Other Lipid Mediat. 2002, 68-69, 177-185. [CrossRef]

2. Matsumoto, H.; Ma, W.; Smalley, W.; Trzaskos, J.; Breyer, R.M.; Dey, S.K. Diversification of cyclooxygenase-2-derived prostaglandins in ovulation and implantation. Biol. Reprod. 2001, 64, 1557-1565. [CrossRef] [PubMed]

3. Huang, J.C.; Wun, W.S.; Goldsby, J.S.; Wun, I.C.; Falconi, S.M.; Wu, K.K. Prostacyclin enhances embryo hatching but not sperm motility. Hum. Reprod. 2003, 18, 2582-2589. [CrossRef] [PubMed]

4. Huang, J.C.; Wun, W.S.; Goldsby, J.S.; Matijevic-Aleksic, N.; Wu, K.K. Cyklooxygenase-2-derived endogenous prostacyclin enhances mouse embryo hatching. Hum. Reprod. 2004, 19, 2900-2906. [CrossRef]

5. Pakrasi, P.L.; Jain, A.K. Cyclooxygenase-2-derived endogenous prostacyclin reduces apoptosis and enhances embryo viability in mouse. Prostaglandins Leukot Essent Fatty Acids 2008, 79, 27-33. [CrossRef]

6. Huang, J.C.; Wun, W.S.; Goldsby, J.S.; Egan, K.; FitzGerald, G.A.; Wu, K.K. Prostacyclin receptor signaling and early embryo development in the mouse. Hum. Reprod. 2007, 22, 2851-2856. [CrossRef]

7. Barak, Y.; Nelson, M.C.; Ong, E.S.; Jones, Y.Z.; Ruiz-Lozano, P.; Chien, K.R.; Koder, A.; Evans, R.M. PPAR $\gamma$ is required for placental, cardiac, and adipose tissue development. Mol. Cell 1999, 4, 585-595. [CrossRef] 
8. Mohan, M.; Malayer, J.R.; Geisert, R.D.; Morgan, G.L. Expression Patterns of Retinoid X Receptors, Retinaldehyde Dehydrogenase, and Peroxisome Proliferator Activated Receptor Gamma in Bovine Preattachment Embryos. Biol. Reprod. 2002, 66, 692-700. [CrossRef]

9. Narumiya, S.; Sugimoto, Y.; Ushikubi, F. Prostanoid Receptors: Structures, Properties, and Functions. Physiol. Rev. 1999, 79, 1193-1226. [CrossRef]

10. Chen, L.; Yang, G.; Grosser, T. Prostanoids and inflammatory pain. Prostaglandins Other Lipid Mediat. 2013, 104-105, 58-66. [CrossRef]

11. Halliwell, R.J.; Berry, E.B.; O'Carroll, S.J.; Mitchell, M.D. Nuclear prostaglandin receptors: Role in pregnancy and parturition? Prostaglandins Leukot Essent Fatty Acids 2004, 70, 149-165. [CrossRef] [PubMed]

12. Namba, T.; Oida, H.; Sugimoto, Y.; Kakizuka, A.; Negishi, M.; Ichikawa, A.; Narumiya, S. cDNA cloning of a mouse prostacyclin receptor. Multiple signaling pathways and expression in thymic medulla. J. Biol. Chem. 1994, 269, 9986-9992.

13. Barak, Y.; Sadovsky, Y.; Shalom-Barak, T. PPAR Signaling in Placental Development and Function. PPAR Res. 2008, 2008, 142082. [CrossRef] [PubMed]

14. Liou, J.Y.; Lee, S.; Ghelani, D.; Matijevic-Aleksic, N.; Wu, K.K. Protection of endothelial survival by peroxisome proliferator-activated receptor-delta mediated 14-3-3 upregulation. Arterioscler. Thromb. Vasc. Biol. 2006, 26, 1481-1487. [CrossRef] [PubMed]

15. Boiani, M.; Eckardt, S.; Schöler, H.R.; McLaughlin, K.J. Oct4 distribution and level in mouse clones: Consequences for pluripotency. Gene Dev. 2002, 16, 1209-1219. [CrossRef] [PubMed]

16. Keramari, M.; Razavi, J.; Ingman, K.A.; Patsch, C.; Edenhofer, F.; Ward, C.M.; Kimber, S.J. Sox2 is essential for formation of trophectoderm in the preimplantation embryo. PLoS ONE 2010, 5, 139-152. [CrossRef]

17. Matsui, M.; Takahashi, Y.; Hishinuma, M.; Kanagawa, H. Stimulation of the development of bovine embryos by insulin and insulin-like growth factor-I (IGF-I) is mediated through the IGF-I receptor. Theriogenology 1997, 48, 605-616. [CrossRef]

18. Liu, H.C.; He, Z.Y.; Mele, C.A.; Veeck, L.L.; Davis, O.K.; Rosenwaks, Z. Expression of IGFs and their receptors is a potential marker for embryo quality. Am. J. Reprod. Immunol. 1997, 38, 237-245. [CrossRef]

19. Rekik, W.; Dufort, I.; Sirard, M.A. Analysis of the gene expression pattern of bovine blastocysts at three stages of development. Mol. Reprod. Dev. 2011, 78, 226-240. [CrossRef]

20. Lonergan, P.; Khatir, H.; Piumi, F.; Rieger, D.; Humblot, P.; Boland, M.P. Effect of time interval from insemination to first cleavage on the developmental characteristics, sex ratio and pregnancy rate after transfer of bovine embryos. J. Reprod. Fertil. 1999, 117, 159-167. [CrossRef]

21. Patel, O.V.; Bettegowda, A.; Ireland, J.J.; Coussens, P.M.; Lonergan, P.; Smith, G.W. Functional genomics studies of oocyte competence: Evidence that reduced transcript abundance for follistatin is associated with poor developmental competence of bovine oocytes. Reproduction 2007, 133, 95-106. [CrossRef]

22. Lechniak, D.; Pers-Kamczyc, E.; Pawlak, P. Timing of the first zygotic cleavage as a marker of developmental potential of mammalian embryos. Reprod. Biol. 2008, 8, 23-42. [CrossRef]

23. Jensen, J.; Orntoft, T. Normalization of real-time quantative PCR data: A model based variance estimation approach to identify genes suited for normalization-applied to bladder-and colon-cancer data-sets. Cancer Res. 2004, 64, 5245-5250.

24. Primer3 Input (Version 0.4.0). Available online: https://bioinfo.ut.ee/primer3-0.4.0/primer3/input.htm (accessed on 23 April 2019).

25. Real-time PCR Miner. Available online: http://miner.ewindup.info (accessed on 23 April 2019).

26. Braissant, O.; Wahli, W. Differential expression of peroxisome proliferator-activated receptor-alpha, -beta, and -gamma during rat embryonic development. Endocrinology 1998, 139, 2748-2754. [CrossRef]

27. Desmarais, J.A.; Lopes, F.L.; Zhang, H.; Das, S.K.; Murphy, B.D. The peroxisome proliferator-activated receptor gamma regulates trophoblast cell differentiation in mink (Mustela vison). Biol. Reprod. 2007, 77, 829-839. [CrossRef] [PubMed]

28. Brooks, K.E.; Burn, G.W.; Spencer, T.E. Peroxisome proliferator activator receptor gamma (PPAG) regulates conceptus elongation in sheep. Biol. Reprod. 2015, 92, 42. [CrossRef] [PubMed]

29. Escher, P.; Braissant, O.; Basu-Modak, S.; Michalik, L.; Wahli, W.; Desvergne, B. Rat PPARs: Quantitative analysis in adult rat tissues and regulation in fasting and refeeding. Endocrinology 2001, 142, 4195-4202. [CrossRef] 
30. Kang, H.J.; Hwang, S.J.; Yoon, J.A.; Jun, J.H.; Lim, H.J.; Yoon, T.K.; Song, H. Activation of peroxisome proliferators-activated receptor $\delta$ (PPAR $\delta$ ) promotes blastocyst hatching in mice. Mol. Hum. Reprod. 2011, 17, 653-660. [CrossRef]

31. Guo, J.; Lu, W.F.; Liang, S.; Choi, J.W.; Kim, N.H.; Cui, X.S. Peroxisome proliferator-activated receptor $\delta$ improves porcine blastocyst hatching via the regulation of fatty acid oxidation. Theriogenology 2017, 90, 266-275. [CrossRef]

32. Cammas, L.; Reinaud, P.; Bordas, N.; Dubois, O.; Germain, G.; Charpigny, G. Developmental regulation of prostacyclin synthase and prostacyclin receptors in the ovine uterus and conceptus during the peri-implantation period. Reproduction 2006, 131, 917-927. [CrossRef]

33. Roberti, S.L.; Higa, R.; White, V.; Powell, T.L.; Jansson, T.; Jawerbaum, A. Critical role of mTOR, PPAR $\gamma$ and PPAR $\delta$ signaling in regulating early pregnancy decidual function, embryo viability and feto-placental growth. Mol. Hum. Reprod. 2018, 24, 327-340. [CrossRef] [PubMed]

34. Sapin, V.; Dollé, P.; Hindelang, C.; Kastner, P.; Chambon, P. Defects of the chorioallantoic placenta in mouse RXRalpha null fetuses. Dev. Biol. 1997, 191, 29-41. [CrossRef] [PubMed]

35. Abdelalim, E.M.; Emara, M.M.; Kolatkar, P.R. The SOX transcription factors as key players in pluripotent stem cells. Stem Cells Dev. 2014, 23, 2687-2699. [CrossRef] [PubMed]

36. Goissis, M.D.; Cibelli, J.B. Functional characterization of SOX2 in bovine preimplantation embryos. Biol. Reprod. 2014, 90, 30. [CrossRef]

37. Khan, D.R.; Dubé, D.; Gall, L.; Peynot, N.; Ruffini, S.; Laffont, L.; Le Bourhis, D.; Degrelle, S.; Jouneau, A.; Duranthon, V. Expression of pluripotency master regulators during two key developmental transitions: EGA and early lineage specification in the bovine embryo. PLoS ONE 2012, 7, e34110. [CrossRef]

38. Foygel, K.; Choi, B.; Jun, S.; Leong, D.E.; Lee, A.; Wong, C.C.; Zuo, E.; Eckart, M.; Pera, R.A.; Wong, W.H.; et al. A novel and critical role for Oct4 as a regulator of the maternal-embryonic transition. PLoS ONE 2008, 3, e4109. [CrossRef]

39. Gendelman, M.; Aroyo, A.; Yavin, S.; Roth, Z. Seasonal effects on gene expression, cleavage timing, and developmental competence of bovine preimplantation embryos. Reproduction 2010, 140, 73-82. [CrossRef]

40. Gendelman, M.; Roth, Z. In vivo vs. in vitro models for studying the effects of elevated temperature on the GV stage oocyte, subsequent developmental competence and gene expression. Anim. Reprod. Sci. 2012, 134, 125-134. [CrossRef]

41. Wang, L.M.; Feng, H.L.; Ma, Y.Z.; Cang, M.; Li, H.J.; Yan, Z.; Zhou, P.; Wen, J.X.; Bou, S.; Liu, D.J. Expression of IGF receptors and its ligands in bovine oocytes and preimplantation embryos. Anim. Reprod. Sci. 2009, 114, 99-108. [CrossRef]

42. Yaseen, M.A.; Wrenzycki, C.; Herrmann, D.; Carnwath, J.W.; Niemann, H. Changes in the relative abundance of mRNA transcripts for insulin-like growth factor (IGF-I and IGF-II) ligands and their receptors (IGF-IR/IGF-IIR) in preimplantation bovine embryos derived from different in vitro systems. Reproduction 2001, 122, 601-610. [CrossRef]

43. El-Sayed, A.; Hoelker, M.; Rings, F.; Salilew, D.; Jennen, D.; Tholen, E.; Sirard, M.A.; Schellander, K.; Tesfaye, D. Large-scale transcriptional analysis of bovine embryo biopsies in relation to pregnancy success after transfer to recipients. Physiol. Genom. 2006, 28, 84-96. [CrossRef] [PubMed]

44. Ghanem, N.; Salilew-Wondim, D.; Gad, A.; Tesfaye, D.; Phatsara, C.; Tholen, E.; Looft, C.; Schellander, K.; Hoelker, M. Bovine blastocysts with developmental competence to term share similar expression of developmentally important genes although derived from different culture environments. Reproduction 2011, 142, 551-564. [CrossRef] [PubMed]

Publisher's Note: MDPI stays neutral with regard to jurisdictional claims in published maps and institutional affiliations.

(C) 2020 by the authors. Licensee MDPI, Basel, Switzerland. This article is an open access article distributed under the terms and conditions of the Creative Commons Attribution (CC BY) license (http://creativecommons.org/licenses/by/4.0/). 